\title{
Reputation, Loneliness, Satisfaction with Life and Aggressive Behavior in Adolescence
}

\author{
Sofía Buelga ${ }^{1}$, Gonzalo Musitu ${ }^{2}$, Sergio Murgui ${ }^{1}$, and Javier Pons ${ }^{1}$ \\ ${ }^{1}$ Universidad de Valencia (Spain) \\ ${ }^{2}$ Universidad Pablo Olavide de Sevilla (Spain)
}

\begin{abstract}
The present study analyses the relationship between adolescents' perception of reputation and aggressive behavior among peers. The sample is made up of 1319 adolescents aged 11 to 16 years old. Statistical analyses with structural equation modeling were carried out to examine the direct and indirect effect of perception of reputation (real and ideal) on aggressive behavior. Results indicate that adolescents' real and ideal reputations are related both directly and indirectly to aggressive behavior. The indirect effects suggest that loneliness and life satisfaction mediate the relationship between adolescents' reputation and their aggressive behavior. These findings and their implications are discussed.

Keywords: adolescents' perception of reputation, aggressive behavior, loneliness, life satisfaction
\end{abstract}

Este trabajo estudia las relaciones entre la percepción de reputación del adolescente y la conducta agresiva entre iguales adolescentes. La muestra está formada por 1319 adolescentes de edades comprendidas entre los 11 y los 16 años. Se utiliza un modelo de ecuaciones estructurales para analizar el efecto directo e indirecto de la reputación (real e ideal) en la conducta agresiva. Los resultados obtenidos confirman que la percepción de reputación real e ideal del adolescente se relaciona tanto directa como indirectamente con la conducta violenta. Los efectos indirectos sugieren que la soledad y la satisfacción con la vida median la relación entre la reputación del adolescente y la conducta agresiva. Se discuten estos resultados y sus implicaciones.

Palabras clave: reputación del adolescente, conducta agresiva, soledad, satisfacción con la vida

This investigation was carried out within the framework of the research project SEJ2004-01742 "Violence and academic integration: Application and assessment of an intervention program at school" financed by the Ministerio de Educación y Ciencia de España and cofinanced by the Dirección General de Investigación y Transferencia.

Correspondence concerning this article should be addressed to Sofía Buelga Vásquez, Universidad de Valencia, Facultad de Psicología, Departamento de Psicología Social, Avda. Blasco Ibáñez, 21, 46010-Valencia (Spain). Phone: 963-864575. E-mail: Sofia.Buelga@uv.es

Translation: Virginia Navascués Howard. 
School violence is currently a great concern in the scientific and educational community (Cava, Musitu, \& Murgui, 2007; Estévez, Murgui, Moreno, \& Musitu, 2007). Although now there is less social tolerance and more sensitivity and knowledge about aggressive behavior in the school scenario, the phenomenon of violent peer behavior is still quite common in the educational setting (Defensor del Pueblo [Ombudsman], 2007; Díaz-Aguado, 2005; Smith, 2003; Smith, Ryan, \& Cousin, 2007).

In fact, recent investigations show that peer aggression, characterized by its intentionality, persistence, and power inequity (Olweus, 1993), represents a problem all over the world (Akiba, 2004; Gofin, Palti, \& Gordon, 2002; Liang, Flisher, \& Lombard, 2007; Smith \& Brain, 2000) that has increased considerably in the last few years (Eisenbraun, 2007; Estévez, Musitu \& Herrero, 2005; Gini, 2006). Olweus (1993, 2001, 2005), pioneer in the study of bullying, states that the frequency of aggressions and victimization in Norway have risen considerably in comparison with the 1980s.

In Spain, despite the social alarm generated by a few severe cases of aggression, the situation of peer maltreatment due to abuse of power has improved in the last decade. The recent report of the Defensor del Pueblo (2007) shows that, compared to 1999, victimization in 2006 decreased by approximately $30 \%$ for the most frequent abuses of direct verbal aggression-insulting and nicknaming-(which dropped from $38.1 \%$ in 1999 to $26.9 \%$ in 2006) and social exclusion-ignoring the other person-(which dropped from $15.1 \%$ in 1999 to $10.5 \%$ in 2006). The percentages of direct—hitting — and indirect physical aggressions_breaking or stealing another's property-(3.7\% in 2006) and indirect verbal aggressions_cursing-(31.6\% in 2006) are similar to those of previous years (Defensor del Pueblo, 2007). According to this report, a decrease was also observed in the occurrence of maltreatment episodes when taking into account the perspectives both of the aggressor and the witnesses. Thus, when assessing self-reports of aggression, a decrease of abusive behavior was also observed in the modalities of physical and verbal aggression, whereas when considering the responses of the spectators' of these abusive episodes - that is, the classmates who witnessed these events - a decrease was also observed in verbal aggression (Defensor del Pueblo, 2007).

Peer violence due to abuse of power, still considered by some people a natural and unavoidable behavior among children and adolescents, is certainly a very serious problem with severe consequences for the psychosocial development and adjustment of the victim (Cava, Musitu, \& Murgui, 2006; Estévez et al., 2007; Hunter, Mora-Merchán, \& Ortega, 2004). Various studies emphasize that such violence is a complex phenomenon of interaction in which several actors intervene: aggressors, victims, and witnesses (Álvarez, Álvarez, GonzálezCastro, Núñez, \& González-Pienda, 2006; Olweus, 2005; Ortega \& Monks, 2005). From the aggressor's viewpoint, the attitude of most witnesses of violent episodes is one of indifference or passivity, when not of outright encouragement or aid. According to the aggressor, less than $10 \%$ of the observers reject abusive behavior (Defensor del Pueblo, 2007).

Spectators' silence and passivity when viewing violent episodes, sometimes justified as fear of becoming the next victim or because of the belief that "it's not my problem" (Díaz-Aguado, 2005) and the reinforcing role of peers who encourage or help the aggressor certainly boosts recognition and social approval of aggressive behavior. It probably also enhances the building and management of a reputation that transgressing adolescents seek intentionally with their violent behavior (Agnew, 1991; Carroll, 2002; Emler \& Reicher, 1995, 2005).

In fact, reputation plays a central role in the life of adolescents (Carroll, 2002; Carroll, Green, Houghton, \& Wood, 2003; Emler \& Reicher, 2005). Various authors have emphasized that reputation, popularity, leadership, and power among peers starts to have real significance in early adolescence (Caroll et al., 2003; Carroll, Houghton, Hattie, \& Durkin, 2001). For some adolescents, reputation is achieved through their involvement in aggressive behavior at the school setting (Gini, 2006), delinquent behavior (Kerpelman \& Smith-Adcock, 2005), drug consumption (Buelga, Ravenna, Musitu, \& Lila, 2006), and disruptive behavior in the classroom (Luthar \& Ansary, 2005).

Scientific literature shows that many aggressors are perceived by their peers as having high status in their peer group (Hawley \& Vaughn, 2003; Vaillancourt, 2002); they are popular and accepted by their classmates (Gini, 2006; Pellegrini \& Bartini, 2000). In this sense, Rodríguez (2004) noted that aggressors in particular have a need of protagonism (being well considered and accepted by others), power (being stronger and more powerful than others), and of being different and exceptional (creating a particular identity in the peer group). These motivations are far removed from the feeling of loneliness that seems to affect the victims (Estévez et al., 2005, 2007; Martin \& Huebner, 2007; Storch \& Masia-Warner, 2004), a sense of loneliness that has profound influence on satisfaction with life (Heinrich \& Gullone, 2006; Toner \& Heaven, 2005).

Many authors find that dissatisfaction with life is associated with internal problems such as depression, anxiety, and low self-esteem (Cava et al., 2007; Chico, 2006; Diener, Sapyta, \& Suh, 1998; Valle, Huebner \& Suldon, 2006). Other authors have observed a relation between the negative appraisal of one's own life and external problems such as drug abuse (Zullig, Valois, Huebner, Oeltman, \& Drane, 2001) and violent behavior (Valois, Zullig, Huebner \& Drane, 2001). In this sense, MacDonald, Piquero, Valois, and Zullig (2005) confirm that satisfaction with life is related to youths' lesser involvement in violent behaviors and vice versa.

In this work, we wished to analyze aggressive peer behavior among adolescents using the following variables: reputation, loneliness, and satisfaction with life, as reflected in Figure 1. 


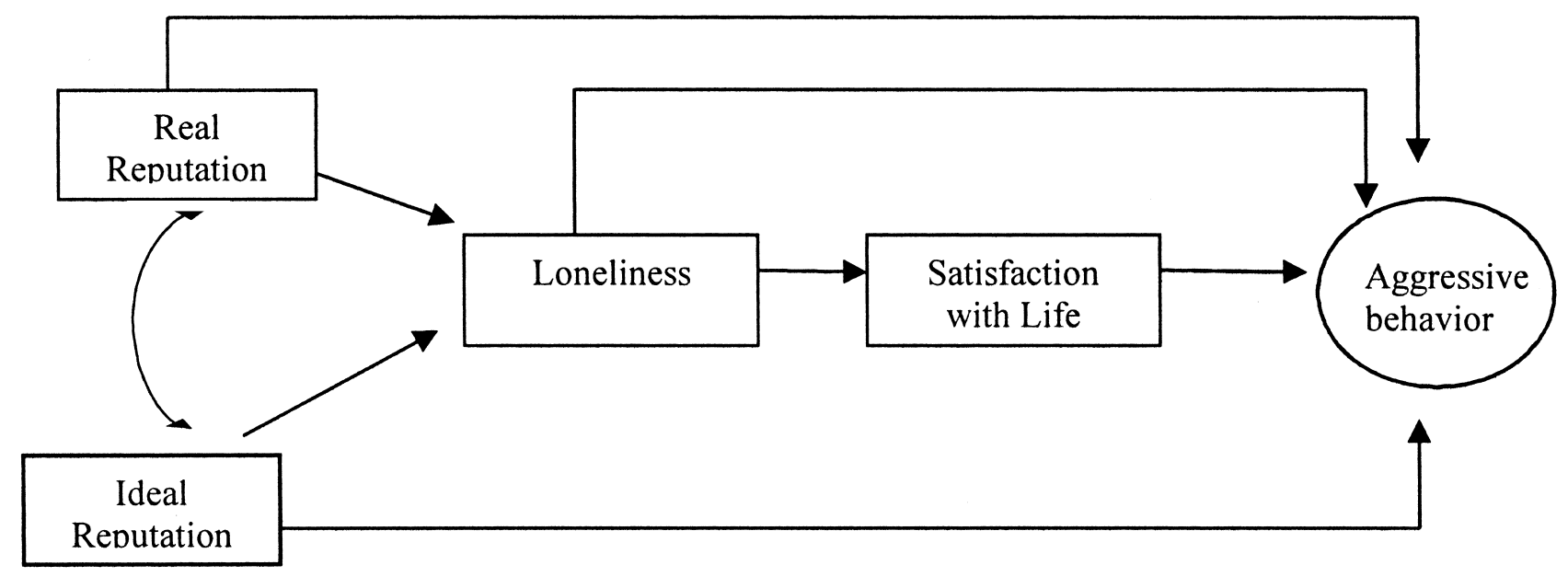

Figure 1. Theoretical model proposed to contrast empirically the direct and indirect effects of reputation on aggressive peer behavior among adolescents.

We propose two main hypotheses:

1. Adolescents' reputation is directly related to aggressive peer behavior. This hypothesis is in accordance with the conceptual assumptions of Emler and Reicher (2005) and Carroll, Houghton, and Baglioni (2000), who differentiated the real reputation from the ideal one. This is an important aspect of this work, to the extent that we hope to verify scientifically the relation between these two dimensions of reputation and aggressive behavior.

2. Adolescents' reputation has an indirect effect on aggressive behavior through loneliness and satisfaction with life. In this sense, we propose that loneliness and satisfaction with life mediate the relation between real and ideal reputation and aggressive peer behavior. In recent investigations, it was confirmed that the perception of being popular and accepted by the peer group protects adolescents from loneliness (Heinrich \& Gullone, 2006; Zettergren, 2005), which, in turn, affects their degree of satisfaction with life (Toner \& Heaven, 2005). And, as noted by MacDonald et al. (2005) and Valois et al. (2001), adolescents' violent behavior is related to their satisfaction with life.

\section{Method}

\section{Participants}

The sample was made up of 1319 adolescents of both sexes (594 males and 725 females), aged between 11 and 16 years $(M=13$ years and 9 months, approximately, $S D$ $=1.48$ ), from 10 teaching centers: four public schools and six concerted schools of the Community of Valencia. Of this sample, $9.4 \%$ of the participants were in the $6^{\text {th }}$ grade of Primary Education, and the rest were students of Compulsory Secondary Education: $25.7 \%$ were in $1^{\text {st }}$ grade, $22.3 \%$ in $2^{\text {nd }}$ grade, $22.5 \%$ were $3^{\text {rd }}$-graders, and $20.1 \%$ were in $4^{\text {th }}$ grade.

\section{Materials}

The Satisfaction with Life Scale (Diener, Emmons, Larsen, \& Griffin, 1985). We used the version of the Satisfaction with Life Scale adapted to Spanish by Atienza, Pons, Balaguer, and García-Merita (2000). The internal consistency of this instrument in its original version (Cronbach's a $=.84$ ) has been confirmed in several recent investigations (Chico, 2006; Extremera, Durán, \& Rey, 2007; Funk, 2005). This instrument is made up of 5 items and provides a general index of satisfaction with life referring to the adolescent's perceived subjective well-being. Responses range between 1 (totally disagree) and 4 (totally agree). In this study, we obtained a Cronbach's alpha reliability coefficient of .74 .

The Revised Loneliness Scale (Russell, Peplau, \& Cutrona, 1980). We applied the version adapted to Spanish by Expósito and Moya (1993). The Cronbach's alpha coefficient of the original version was .89. This scale comprises 20 items that assess the degree of the adolescent's loneliness, with a response range going from 1 (never) to 4 (always). In our study, we obtained a Cronbach's alpha reliability coefficient of .90 .

Scale of Overt Aggression among Peers (adapted from Little, Henrich, Jones, \& Hawley, 2003). This 13-item instrument measures overt or direct aggression towards a victim on a rating scale that ranges from 1 (total disagree) to 4 (totally agree). The authors obtained a Cronbach's alpha of .89. This measuring instrument has 3 dimensions that assess Overt Aggression: pure aggression (i.e., "I am the 
kind of person who hits or punches others"), reactive aggression (i.e., "When I'm hurt by someone, I often fight back"), and instrumental aggression (i.e., "To get what I want, I often threaten others"). The Cronbach's alpha reliability coefficient obtained in the present study was .71 for pure aggression, measured with 4 items, .81 for reactive aggression (3 items), and .79 for instrumental aggression (3 items). The Cronbach's alpha reliability coefficient for the entire scale of overt aggression was .91.

Perception of Reputation Scale (adapted from Carroll, Baglioni, Houghton, \& Bramston, 1999; Carroll, Houghton, \& Baglioni, 2000). This scale is a factor of the Reputation Enhancement Scale by Carroll and colleagues (Carroll et al., 1999, 2000). The factor is made up of 15 items that reflect two situations: real reputation (Cronbach's $\alpha=.77$ in the original version of the scale) and ideal reputation (Cronbach's $\alpha=.78$ in the original version). Both perceptions of reputation have the same dimensions: nonconformist self-perception (Cronbach's $\alpha$ of real perception $=.83$, Cronbach's $\alpha$ of ideal perception $=.81$ ), conformist self-perception (Cronbach's $\alpha$ of real perception $=.78$, Cronbach's $\alpha$ of ideal perception $=.77$ ), and reputational self-perception (Cronbach's $\alpha$ of real perception $=.77$, Cronbach's $\alpha$ of ideal perception $=.78$ ).

In this investigation, we used the factor of Self-Perception of Reputation, because we considered that it offers the best synthesis of the concept of reputation, according to the authors of the original questionnaire (Carroll et al., 1999) and Emler and Reicher (1995, 2005). The 4-item Self-Perception of Reputation subscale, with a rating response ranging from 1 (never) to 4 (always), measures the adolescent's perception of real and ideal reputation. The scale assesses the following aspects with the same 4 items: (a) what adolescents believe that others think about their reputation-perception of real reputation (i.e., "Others think I'm popular;" "Others think I have a good reputation") — and (b) what adolescents would like others to think about their reputation-perception of ideal reputation (i.e., "I'd like others to think I was a leader;" "I'd like others to think I'm strong"). Cronbach's alpha reliability coefficient was .68 for the Real Reputation subscale and .75 for the Ideal Reputation subscale.

\section{Design and Procedure}

Students were selected by cluster sampling (Santos, Muñoz, Juez, \& Cortiñas, 2003). The sampling units were the private and concerted educational centers of Primary and Compulsory Secondary Education from the Community of Valencia. Three educational centers were randomly selected from the province of Alicante, three from the province of Castellón, and four from the province of Valencia. Of the 10 selected centers, two public centers and one concerted center refused to participate in the investigation because of internal functioning problems. The above procedure was followed until ten centers were selected.
In each of the educational centers, the questionnaires were administered to all the students of Primary and Compulsory Secondary Education, comprising a total sample of 1319 adolescents. Taking into account the total number of students of Compulsory Secondary Education (241.808 students) in the Community of Valencia and the procedure of sampling used, the representativeness of the sample is guaranteed.

Once the 10 educational centers had been selected, the research team met with the Board of Directors and the teachers to explain the goals, procedure, and scope of the present investigation. We also requested parental permission through the children by means of a letter in which we informed the parents of the purpose of the project, and asked them to return their signed consent to the school. After all the permissions had been obtained, previously trained investigators administered the instruments. The responses were anonymous. Participants were informed that their data were confidential and that they could refuse to answer. No participants refused to respond.

\section{Data Analysis}

We used Student's $t$ for independent samples to determine whether there were statistically significant sex differences in the variables of interest.

Subsequently, we applied structural equation modeling to test the fit of the model proposed in this work (see Figure 1), using the maximum likelihood method by means of the EQS 6.1 program (Bentler, 1995). As the data deviated from multinormality (normalized Mardia's coefficient $=4.53$ ), we used robust estimators to determine the goodness of fit of the model and the statistical significance of the coefficients. However, as $\mathrm{Hu}$ and Bentler (1999) advise researchers not to use just one measure of global model fit, we calculated the following goodnessof-fit indexes: Chi-square compared with its degree of freedom, the robust comparative fit index (robust CFI), Bentler-Bonett's nonnormed fit index (NNFI), the goodness of fit index (GFI), the adjusted goodness of fit index (AGFI), and the root mean square error of approximation (RMSEA). A model is considered to fit the observed data well when the ratio between the chi-square statistic and the degrees of freedom is less than 3, the goodness-of-fit indexes are equal to or higher than .90, and the RMSEA is lower than .05 (Hu \& Bentler, 1999; Jöreskog \& Sörbom, 1993). Lastly, we estimated the standardized regression coefficients included in the model, analyzing their level of significance.

\section{Results}

Table 1 displays the correlation matrix of the variables and their means (general and as a function of sex). Exploratory correlation analysis confirmed statistically 
Table 1

Means (Standard Deviations), Intergroup Comparisons (Student's t), and Correlation Matrix of the Variables of the Model

\begin{tabular}{|c|c|c|c|c|c|c|c|c|}
\hline Variables & $M(S D)$ & 1 & 2 & 3 & 4 & 5 & 6 & 7 \\
\hline 1. Real Reputation & $9.3(2.2)$ & - & & & & & & \\
\hline 2. Ideal Reputation & $10.3(2.4)$ & $-.55^{* *}$ & - & & & & & \\
\hline 3. Loneliness & $38.4(8.7)$ & $-.10 * *$ & $-.37 * *$ & - & & & & \\
\hline 4. Satisfaction with Life & $14.1(2.1)$ & .00 & $.16^{* *}$ & $-.47 * *$ & - & & & \\
\hline 5. Pure aggression & $6.3(2.0)$ & $.18 * *$ & $.15^{* *}$ & $.10 * *$ & $-.18 * *$ & - & & \\
\hline 6. Reactive aggression & $7.2(2.7)$ & $.18 * *$ & $.16^{* *}$ & .057 & $-.14 * *$ & $.60 * *$ & - & \\
\hline 7. Instrumental aggression & $6.7(2.4)$ & $-.24 * *$ & $.17 * *$ & $.11 * *$ & $-.19 * *$ & $.69 * *$ & $.59 * *$ & - \\
\hline $\begin{array}{l}M \text { Males / Females } \\
(t \text { value })\end{array}$ & & $\begin{array}{l}9.6 / 9.0 \\
(4.3)\end{array}$ & $\begin{array}{r}10.6 / 10.0 \\
(3.3)^{* * *}\end{array}$ & $\begin{array}{l}38.4 / 38.4 \\
\quad(.09)\end{array}$ & $\begin{array}{l}14.6 / 14.6 \\
(.70)\end{array}$ & $\begin{array}{l}6.6 / 5.6 \\
(7.1)^{*}\end{array}$ & $\begin{array}{c}8.0 / 6.3 \\
(12.4)^{*}\end{array}$ & $\begin{array}{c}7.2 / 6.2 \\
(7.7)^{*}\end{array}$ \\
\hline
\end{tabular}

$* p<.05 . * * p<.01 . * * * p<.001$ (in all cases, bilateral).

significant correlations among most of the variables of interest in this work. In this table can be seen, firstly, that the real and ideal reputation correlated positively with the diverse kinds of aggression, except for the negative correlation between real reputation and instrumental aggression $(r=-.24, p<.01)$. Thus, positive correlations were observed between real reputation and pure aggression $(r=.18, p<.01)$ and between real reputation and reactive aggression $(r=.18, p<.01)$. Ideal reputation also correlated positively with pure aggression $(r=.15, p<.01)$, reactive aggression $(r=.16, p<.01)$, and instrumental aggression $(r=.17, p<.01)$. In contrast, the correlation between loneliness and satisfaction with life was negative $(r=-.47$, $p<.01)$. Satisfaction with life was also observed to correlate negatively with the diverse forms of violent behavior.

Regarding the means of these variables, statistically significant sex differences can also be seen in Table 1. Specifically, we note that the males' means were significantly higher than the females' in ideal reputation $(t=3.3, p<$ $.001)$, pure aggression $(t=7.1, p<.05)$, reactive aggression $(t=12.4, p<.05)$, and instrumental aggression $(t=7.7, p$ $<.05)$. No statistically significant differences were revealed between males and females in the variables of real reputation, loneliness, and satisfaction with life,

Table 2

Parameter Estimations and Standard Errors of Direct Violent Behavior

\begin{tabular}{lcc}
\hline $\begin{array}{l}\text { Dimensions of overt } \\
\text { aggression }\end{array}$ & $\begin{array}{c}\text { Factor } \\
\text { Loadings }\end{array}$ & $\begin{array}{c}\text { Standard } \\
\text { Errors }\end{array}$ \\
\hline Pure aggression & $1^{\mathrm{a}}$ & 0 \\
Instrumental aggression & $.94^{* * *}$ & .04 \\
Reactive aggression & $.90^{* * *}$ & .04 \\
\hline
\end{tabular}

Note. Robust statistics. ${ }^{\text {a }}$ Fixed at 1.00 during the estimation. $* * * p<.005$ (bilateral)
After standardizing the variables of the model, we calculated a structural equation model to analyze the influence of reputation (real and ideal) on adolescents' aggression. The model is made up of four observable variables (real reputation, ideal reputation, loneliness, satisfaction with life) and a latent factor, denominated overt aggression, which is made up of the following variables: pure overt aggression, overt instrumental aggression, and overt reactive aggression. The factor loadings of this factor are shown in Table 2.

As displayed in Figure 2, the proposed model fit the data well: $\mathrm{S}-\mathrm{B} \chi^{2}(11, N=1319)=22.72(p<.001) ; \chi^{2} / d f=$ 2.06; NNFI $=.98, \mathrm{CFI}=.99, \mathrm{GFI}=.99, \mathrm{RMSEA}=.030$. For the goodness-of-fit indexes CFI, GFI, and NNFI, values over .95 are considered acceptable, and for RMSEA, values lower than .05 (Batista \& Coenders, 2000). In all cases, the index values were over .98 , which indicates a good fit of the model to the data. This model explained $16.3 \%$ of the variance of aggressive peer behavior among adolescent.

The results reveal interesting relations among the variables of the model. Thus, direct relations are observed between the perception of reputation and aggressive behavior. These relations are different depending on whether the reputation is real or ideal. Thus, the need for a better reputation (ideal reputation) was seen to be positively related to overt aggression amongst peers $(\beta=.19, p<.001)$, whereas the perception of being socially recognized by peers (real reputation) was negatively related to aggression $(\beta=$ $-.12, p<.001)$. Real and ideal reputation presented a correlation of -57 .

We also found indirect relations among the perception of real and ideal reputation and aggression through loneliness and satisfaction with life. On the one hand, the perception of real and ideal reputation again affected these variables in opposite directions. The perception real of reputation $(\beta$ $=.49, p<.001)$ and of ideal reputation $\beta=.17, p<.001$ ) directly affected the degree of loneliness experienced by adolescents. The wish for a better reputation was positively 


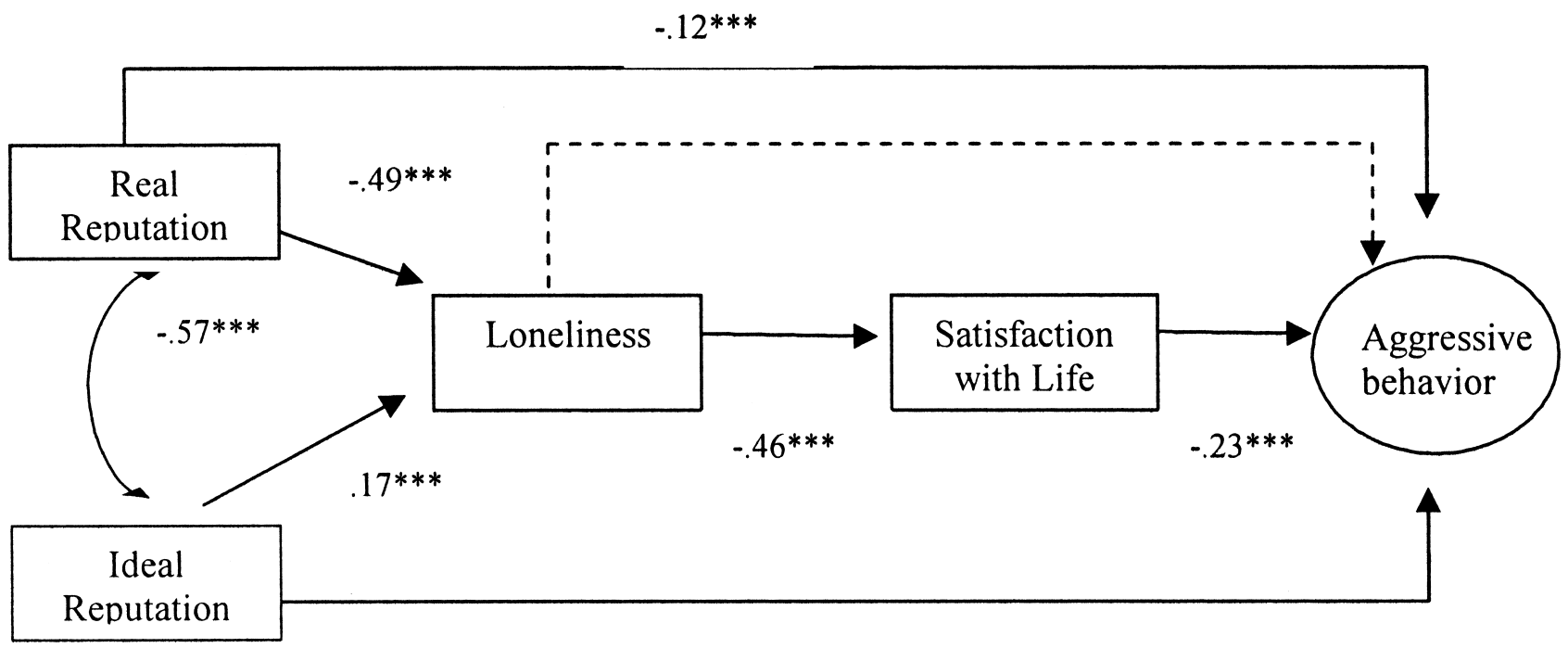

$.19 * * *$

Figure 2. Standardized solution of the model.

The statistical significance of the relations was determined from the robust standard error. Continuous lines represent significant paths among variables. $\chi^{2}(11, N=1319)=22.72, \chi^{2} / d f=2.06, \mathrm{CFI}=.99, \mathrm{GFI}=.99$, NNFI $=.98, \mathrm{AGFI}=.98, \mathrm{RMSEA}=.030$. $* * * p<.001$.

related to the feeling of loneliness, whereas the perception of peers' social recognition had a negative relationship with loneliness. The results also show that the relation between the feeling of loneliness and aggression was not statistically significant, whereas the relation between loneliness and satisfaction with life was significant $(\beta=-.46, p<.001)$. Satisfaction with life had a direct and negative effect on aggression $(\beta=-.23, p<.001)$ in the sense that it decreased aggression among peer adolescents.

\section{Discussion}

In this study, we analyzed the influence of the perception of the reputation (real and ideal) on aggressive behavior among peer adolescents. As hypothesized, the results of the study confirm that the perception both of the real and the ideal reputation has a direct and an indirect effect on peer aggression.

The direct effect of the perception of the reputation and aggressive behavior is of great interest. This relation seems to support the notion that adolescents' aggression may be a strategy to achieve power and status within the peer group (Cillessen \& Borch, 2006; Smith \& Brain, 2000), and also a means to satisfy certain needs involving social approval, as noted by Rodríguez (2004). This idea is clearly reflected in the results of the perception of ideal reputation, which indicate the existence of a direct relation between the desire for more social recognition from peers and aggressive behavior. According to our results, the wish for more social approval ("I wish: others would think of me as a leader;"
"I were popular;" "I were strong;" "I had a good reputation") directly intervenes in overt peer aggression among adolescents. Thus, the need for a better reputation and social prestige among peers has a direct effect in the adolescent's involvement in violent behavior, and such behavior is more frequent among males than among females (Cowie, 2000). In fact, Ortega and Monks (2005) found that already at the preschool stage, direct aggressive behaviors (both physical and verbal) are more common in male children than in females. At all educational stages, boys are observed to be more involved in direct aggression, whereas girls tend more toward indirect aggression (Defensor del Pueblo, 2007; Gini, 2006; Kochenderfer-Ladd \& Wardrop, 2001; Tapper \& Boulton, 2004).

However, as noted in the studies of Carroll (2002), Carroll et al. (2001, 2003), and Emler and Reicher (1995, 2005), managing their reputation, a fundamental aspect in the life of adolescents, not only intervenes in their transgressions, but also in their adaptive behaviors. In this sense, Carroll et al. (2001) and Carroll (2002) state that many adolescents build their reputation on behaviors that are not aimed at transgressional settings (for example, sports, or art), which is in accordance with our results. Overt peer aggression is not so much determined by reputation itself but by adolescents' dissatisfaction with the reputation they want to achieve in the peer group (ideal reputation).

Another relevant aspect of our work, which confirms our second hypothesis, are the indirect relations observed between reputation and aggression through loneliness and dissatisfaction with life. Our results coincide with recent investigations (Heinrich \& Gullone, 2006; Storch, Phil, 
Nock, Masia-Warner, \& Barlas, 2003; Zettergren, 2005), which indicate that the perception of popularity and leadership in the peer group protects adolescents from feeling of loneliness. An interesting find, which deserves more attention from investigators, is the fact that loneliness does not have a statistically significant relation with aggression. Some authors have verified that aggressors, in contrast to victims, do not present problems of loneliness, because they have a social support network that grants them esteem, respect, and confidence and that, at the same time, values them positively in terms of leadership and popularity (Estévez et al., 2005; Ireland \& Power, 2004; Pellegrini \& Bartini, 2000). However, our results indicate that loneliness intervenes directly in satisfaction with life, which is in accordance with the evidence obtained in this field of study (Heinrich \& Gullone, 2006; Toner \& Heaven, 2005). This confirms how important it is for adolescents' psychosocial well-being to be integrated in social support networks that protect them from loneliness (Buelga \& Musitu, 2006; Musitu, Buelga, Lila, \& Cava, 2001). Although many works have studied satisfaction with life in adolescence (Funk, 2005; Gilligan \& Huebner, 2002; Huebner, 1991), very few have related this psychological variable to aggressive behavior (MacDonald et al., 2005; Valois et al., 2001). In this sense, the multiple relations of dependence analyzed in our work contribute to enriching this relevant area of study and to clarifying the role of loneliness and satisfaction with life in the relation between reputation (real and ideal) and overt peer aggression among adolescents.

On the one hand, as we have seen, satisfaction with life is directly related to the feeling of loneliness, which, in turn, is affected by the perception of reputation. On the other hand, as derived from a recent work of MacDonald et al. (2005), our results also confirm the existence of a negative relation between satisfaction with life and aggressive peer behavior, which suggests that satisfaction with life is an important protective factor against peer violence. Consequently, in view of these results, it can be concluded that reputation has a statistically significant relation with adolescent peer aggression and that this relation is significantly enhanced when the variables loneliness and satisfaction with life are included.

In short, this work contributes very suggestive and novel data about the involvement of certain psychosocial variables in the explanation of adolescent peer aggression. However, it is important to point out that, despite the fact that the test were administered anonymously and the reliability indexes obtained were acceptable, the fact that the adolescents completed the instruments may be biased by social desirability and insincere responses. However, as various authors note, the reliability and validity of adolescents' selfreports when measuring risk behaviors such as criminal and violent behavior is acceptable (Flisher, Evans, Muller, \& Lombard, 2004; Ritakallio, Kaltiala-Heino, Kivivuori, \& Rimpelä, 2005).
Likewise, another limitation of this work is that the interpretation of the results in causal terms should be taken with caution because of the correlational nature of the design. This work may guide future research that analyzes the relations examined herein in more depth, thus contributing to improving our understanding of the problem of aggressive peer behavior among adolescents, and so, to designing effective prevention programs. In this sense, the construction and management of reputation should be included in programs of prevention of violent behavior in the school setting, as this is undoubtedly a very important variable in the life of adolescents.

\section{References}

Agnew, R. (1991). The interactive effects of peer variables on delinquency. Criminology, 29, 47-72.

Akiba, M. (2004). Nature and correlates of Ijime-Bullying in Japanese middle school. International Journal of Educational Research, 41, 216-236.

Álvarez, L., Álvarez, D., González-Castro, P., Núñez, J.C., \& González-Pienda, J.A. (2006). Evaluación de los comportamientos violentos en los centros educativos. Psicothema, 18, 686-695.

Atienza, F.L., Pons, D., Balaguer, I., \& García-Merita, M. (2000). Propiedades psicométricas de la escala de satisfacción con la vida en adolescentes. Psicothema, 12, 314-320.

Batista, J.M., \& Coenders, G. (2000). Modelos de ecuaciones estructurales. Madrid: Editorial La Muralla.

Bentler, P.M. (1995). EQS structural equations program manual. Encino, CA: Multivariate Software.

Buelga, S., \& Musitu, G. (2006). Famille et Adolescence: Prévention de conduites à risque. In M. Zabalia \& D. Jacquet (Eds.), Adolescences d'aujourd'hui (pp. 17-35). Rennes: Presses Universitaires de France.

Buelga, S., Ravenna, M., Musitu, G., \& Lila, M.S. (2006). Epidemiology and psychosocial risk factors associated with adolescents' drug consumption. In S. Jackson \& L. Goossens (Eds.), Handbook of adolescent development (pp. 337-369). Hove, UK: Psychology Press.

Carroll, A. (2002). At-risk and not at-risk adolescent girls in singlesex and mixed-sex school settings: An examination of their goals and reputation. Westminster Studies in Education, 2, 147162.

Carroll, A., Baglioni, A.J., Houghton, S., \& Bramston, P. (1999). At-risk and not at-risk primary school children: An examination of goal orientations and social reputations. British Journal of Educational Psychology, 69, 377-392.

Carroll, A., Green, S., Houghton, S., \& Wood, R. (2003). Reputation enhancement and involvement in delinquency among high school students. International Journal of Disability, Development and Education, 50, 253-273.

Carroll, A., Houghton, S., \& Baglioni, J.R. (2000). Goals and reputations amongst young children. The validation of the 
importance of goals and reputation enhancement scales. Social Psychology International, 21, 115-135.

Carroll, A., Houghton, S., Hattie, J., \& Durkin, K. (2001). Reputation enhancing goals: Integrating reputation enhancement and goals setting theory as explanation of delinquent involvement. In F.H Columbus (Ed.), Advances in psychology research: Vol. 4. (pp. 101-109). New York: Nova Science Publishers.

Cava, M.J., Musitu, G., \& Murgui, S. (2006). Familia y violencia escolar: el rol mediador de la autoestima y la actitud hacia la autoridad institucional. Psicothema, 18, 367-373.

Cava, M. J., Musitu, G., \& Murgui, S. (2007). Individual and social risk factors related to overt victimization in a sample of Spanish adolescents. Psychological Reports, 101, 275-290.

Chico, E. (2006). Personality dimensions and subjective well-being. The Spanish Journal of Psychology, 1, 38-44.

Cillessen, A., \& Borch, C. (2006). Developmental trajectories of adolescent popularity: A growth curve modelling analysis. Journal of Adolescence, 29, 935-959.

Cowie, H. (2000). Bystanding or standing by: Gender issues in coping with bullying in schools. Aggressive Behavior, 26, 8597.

Defensor del Pueblo (2007). Violencia escolar: el maltrato entre iguales en la Educación Obligatoria Secundaria 1999. 2006. Madrid: Publicaciones de la Oficina del Defensor del Pueblo.

Díaz-Aguado, M.J. (2005). La violencia entre iguales en la adolescencia y su prevención desde la escuela. Psicothema, 17, 549-558.

Diener, E., Emmons, R., Larsen, R.J., \& Griffin, S. (1985). The Satisfaction with Life Scale. Journal of Personality Assessment, 49, 71-75.

Diener, E., Sapyta, J., \& Suh, E. (1998). Subjective well-being is essential to well-being. Psychological Inquiry, 9, 33-37.

Eisenbraun, K.D. (2007). Violence in schools: Prevalence, prediction, and prevention. Aggression and Violent Behavior, 12, 459-469.

Emler, N., \& Reicher, S. (1995). Adolescence and delinquency. Oxford: Blackwell.

Emler, N., \& Reicher, S. (2005). Delinquency: Cause or consequence of social exclusion? In D. Abrams, J. Marques, \& M. Hogg (Eds.), The social psychology of inclusion and exclusion (pp. 211-241). Philadelphia, PA: Psychology Press.

Estévez, E., Murgui, S., Moreno, D., \& Musitu, G. (2007). Estilos de comunicación familiar, actitud hacia la autoridad institucional y conducta violenta del adolescente en la escuela. Psicothema, 19, 108-113.

Estévez, E., Musitu, G., \& Herrero, J. (2005). The influence of violent behavior and victimization at school on psychological distress: The role of parents and teachers. Adolescence, 40, 183-195.

Expósito, F., \& Moya, M. (1993). Validación de la UCLA Loneliness Scale en una muestra española. In F. Loscertales, \& M. Marín (Eds.), Dimensiones psicosociales de la educación y de la comunicación (pp. 355-364). Sevilla: Eudema.
Extremera, N., Durán, A., \& Rey, L. (2007). Perceived emotional intelligence and dispositional optimism-pessimism: Analyzing their role in predicting psychological adjustment among adolescents. Personality and Individual Differences, 42, 10691079.

Flisher, A.J., Evans, J., Muller, M., \& Lombard, C. (2004). Brief report: Test-retest reliability of self-reported adolescent risk behavior. Journal of Adolescence, 27, 207-212.

Funk, B.A. (2005). Validation of a Brief Students' Life Satisfaction Scale with adolescents. Dissertation Abstracts International: Section B: The Sciences and Engineering, 65, 12-B, 6650.

Gilligan, T.D., \& Huebner, E.S. (2002). Multidimensional life satisfaction report of adolescents: A multitrait-multimethod study. Personality and Individual Differences, 32, 1149-1155.

Gini, G. (2006). Bullying as a social process: The role of group membership in students' perception of inter-group aggression at school. Journal of School Psychology, 44, 51-65.

Gofin, R., Palti, H., \& Gordon, L. (2002). Bullying in Jerusalem schools: Victims and perpetrators. Public Health, 116, 173178.

Hawley, P., \& Vaughn, B. (2003). Aggression and adaptation: The bright side to bad behavior. Introduction to special volume. Merrill-Palmer Quarterly, 49, 239-244.

Heinrich, L.M., \& Gullone, E. (2006). The clinical significance of loneliness: A literature review. Clinical Psychology Review, 26, 695-718.

Hu, L., \& Bentler, P.M. (1999). Cutoff criteria for fit indexes in covariance structure analysis: Conventional criteria versus new alternatives. Structural Equation Modeling, 6, 1-55.

Huebner, E.S. (1991). Initial development of the Student's Life Satisfaction Scale. School Psychology International, 12, 231240.

Hunter, S.C., Mora-Merchán, J., \& Ortega, R. (2004). The longterm effects of coping strategy use in victims of bullying. The Spanish Journal of Psychology, 7, 3-12.

Ireland, J.L., \& Power, C.L. (2004). Attachment, emotional loneliness, and bullying behavior: A study of adult and young offenders. Aggressive Behavior, 30, 298-312.

Jöreskog, K., \& Sörbom, D. (1993). Lisrel 8. Structural equation modelling with the SIMPLIS command language. Chicago, IL: Scientific Software International.

Kerpelman, J.L., \& Smith-Adcock, S. (2005). Female adolescents' delinquent activity. The intersection of bonds to parents and reputation enhancement. Youth and Society, 37, 176-200.

Kochenderfer-Ladd, B., \& Wardrop, J.L. (2001). Chronicity and instability of children's peer victimization experiences as predictors of loneliness and social satisfaction trajectories. Child Development, 72, 134-151.

Liang, H., Flisher, A.J., \& Lombard, C.J. (2007). Bullying, violence, and risk behavior in South African school students. Journal of Child Abuse and Neglect, 31, 161-171.

Little, T.D., Henrich, C.C., Jones, S.M., \& Hawley, P.H. (2003). Disentangling the "whys" from the "whats" of aggressive behavior. International Journal of Behavioral Development, 27, 122-133. 
Luthar S., \& Ansary N. (2005). Dimensions of adolescent rebellion: Risk for academic failure among high and low-income youth. Development and Psychopathology, 17, 231-250.

MacDonald, J., Piquero, A., Valois, R., \& Zullig, K. (2005). The relationship between life satisfaction, risk-taking behaviors and youth violence. Journal of Interpersonal Violence, 20, 1495-1518.

Martin, K.M., \& Huebner, E.S. (2007). Peer victimization and prosocial experiences and emotional well-being of middle school students. Psychology in the Schools, 44, 199-208.

Musitu, G., Buelga, S., Lila, M.S., \& Cava, M.J. (2001). Familia y adolescencia. Madrid: Síntesis.

Olweus, D. (1993). Bullying at school: What we know and what we can do. Oxford, UK: Blackwell.

Olweus, D. (2001). Olweus' core program against bullying and antisocial behavior: A teacher handbook. Bergen, Norway: Research Centre for Health Promotion.

Olweus, D. 1995. Peer abuse or bullying at school: Basic facts and a school-based intervention programme. Prospects, 25, 133-139. [Spanish translation: Bullying en la escuela: datos e intervención. In J. Sanmartín (Ed.), Violencia y escuela (pp. 13-30). Valencia: Centro Reina Sofía para el Estudio de la Violencia, 2005].

Ortega, R., \& Monks, C. (2005). Agresividad injustificada entre preescolares. Psicothema, 17, 453-458.

Pellegrini, A.D., \& Bartini, M. (2000). A longitudinal study of bullying, victimization, and peer affiliation during the transition from primary school to middle school. American Educational Research Journal, 37, 699-725.

Ritakallio, M., Kaltiala-Heino, R., Kivivuori, J., \& Rimpelä, M. (2005). Brief report: Delinquent behavior and depression in middle adolescence: a Finnish community sample. Journal of Adolescence, 28, 155-159.

Rodríguez, N. (2004). Guerra en las aulas. Madrid: Editorial Temas de Hoy.

Russell, D., Peplau, L.A., \& Cutrona, C.E. (1980). The revised UCLA Loneliness Scale: Concurrent and discriminant validity evidence. Journal of Personality and Social Psychology, 39, 472-480.

Santos, J., Muñoz, A., Juez, P., \& Cortiñas, P. (2003). Diseño de encuestas de estudio de mercado. Técnicas de muestreo y análisis multivariente. Madrid: Fundación Ramón Areces.

Smith, J.D., Ryan, W., \& Cousin, J.B. (2007). Antibullying programs: A survey of evaluation activities in public school. Studies in Educational Evaluation, 33, 120-134.
Smith, P.K. (2003). Violence in schools, the response in Europe. London: Routledge.

Smith, P.K., \& Brain, P.F. (2000). Bullying in schools: Lessons from two decades of research. Aggressive Behavior, 26, 19.

Storch, E.A., \& Masia-Warner, C. (2004). The relationship of peer victimization to social anxiety and loneliness in adolescent females. Journal of Adolescence, 27, 351-362.

Storch, E., Phil, M., Nock, M.K., Masia-Warner, C., \& Barlas, M.E. (2003). Peer victimization and social-psychological adjustment in Hispanic and African-American children. Journal of Child \& Family Studies, 12, 439-452.

Tapper, K., \& Boulton, M.J. (2004). Sex differences in levels of physical, verbal, and indirect aggression amongst primary school children and their associations with beliefs about aggression. Aggressive Behavior, 30, 123-145.

Toner, M.A., \& Heaven, P. (2005). Peer-social attributional predictors of social emotional adjustment in early adolescence: A two year longitudinal study. Personality and Individual Differences, 38, 579-590.

Vaillancourt, T. (2002). Competing for hegemony during adolescence: A link between aggression and social status. Dissertation Abstracts International Section A: Humanities and Social Sciences, 62, 8-A, 2684-268.

Valle, M., Huebner, S., \& Suldon, S. (2006). An analysis of hope as a psychological strength. Journal of School Psychology, 44, 393-406.

Valois, R.F., Zullig, K.J., Huebner, E.S., \& Drane, W. (2001). Relationship between life satisfaction and violent behaviors among adolescents. American Journal of Health Behavior, 25, 353-366.

Zettergren, P. (2005). Childhood peer status as a predictor of a midadolescence peer situation and social adjustment. Psychology in the School, 42, 745-756.

Zullig, K.J., Valois, R.F., Huebner, E.S., Oeltman, J.E., \& Drane, W. (2001). Relation between perceived life satisfaction and adolescents' substance abuse. Journal of Adolescent Health, 29, 279-288.

Received February, 20, 2007

Revision received October, 16, 2007 Accepted November, 23, 2007 